\title{
Emotion recognition based on multimodal fusion using mixture of brain emotional learning
}

\author{
Zeinab Farhoudi', Saeed Setayeshi* (iD, Farbod Razazi ${ }^{3}$, Azam Rabiee ${ }^{4}$
}

1. PhD Student of Artificial Intelligence, Department of Computer Engineering, Science and Reserach Branch, Islamic Azad University, Tehran, Iran

2. Professor of Department of Energy Engineering and Physics, Amirkabir University of Technology, Tehran, Iran

3. Professor of Department of Electrical and Computer Engineering, Science and Reserach Branch, Islamic Azad University, Tehran, Iran

4. Professor of Department of Computer Science, Dolatabad Branch, Islamic Azad University, Isfahan, Iran

Recieved: 6 Mar. 2019

Revised: 6 Sep. 2019

Accepted: 16 Sep. 2019

\section{Keywords}

Multimodal emotion recognition

Brain emotional learning

Mixture of neural networks

Fusion

Deep learning

\section{Corresponding author}

Saeed Setayeshi, Professor of Department of Energy Engineering and Physics, Amirkabir University of Technology, Tehran, Iran

Email: Setayesh@aut.ac.ir

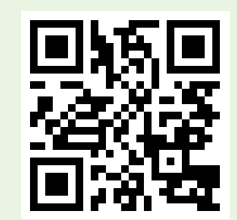

\section{Abstract}

Introduction: Multimodal emotion recognition due to receiving information from different sensory resources (modalities) from a video has a lot of challenges and has attracted many researchers as a new method of human computer interaction. The purpose of this paper was to automatically recognize emotion from emotional speech and facial expression based on the neural mechanisms of the brain. Therefore, based on studies on brain-inspired models, a general framework for bimodal emotion recognition inspired by the functionality of the auditory and visual cortics and brain limbic system is presented. Methods: The hybrid and hierarchical proposed model consisted of two learning phases. The first step: the deep learning models for the representation of visual and auditory features, and the second step: a Mixture of Brain Emotional Learning (MoBEL) model, obtained from the previous stage, for fusion of audio-visual information. For visual feature representation, 3D-convolutional neural network (3D-CNN) was used to learn the spatial relationship between pixels and the temporal relationship between the video frames. Also, for audio feature representation, the speech signal was first converted to the $\log$ Mel-spectrogram image and then fed to the CNN. Finally, the information obtained from the two above streams was given to the MoBEL neural network model to improve the efficiency of the emotional recognition system by considering the correlation between visual and auditory and fusion of information at the feature level.

Results: The accuracy rate of emotion recognition in video in the eNterface'05 database using the proposed method was on average of $82 \%$.

Conclusion: The experimental results in the database show that the performance of the proposed method is better than the hand-crafted feature extraction methods and other fusion models in the emotion recognition.

Citation: Farhoudi Z, Setayeshi S, Razazi F, Rabiee A. Emotion recognition based on multimodal fusion using mixture of brain emotional learning. Advances in Cognitive Sciences. 2020;21(4):113-127. 


\section{بازشناسى هيجان مبتنى بر همجوشى اطلاعات جنلووجهى با استفاده از مدل تر كيبى يادكيرى هيجاذى مغز}

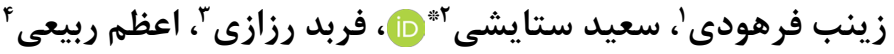

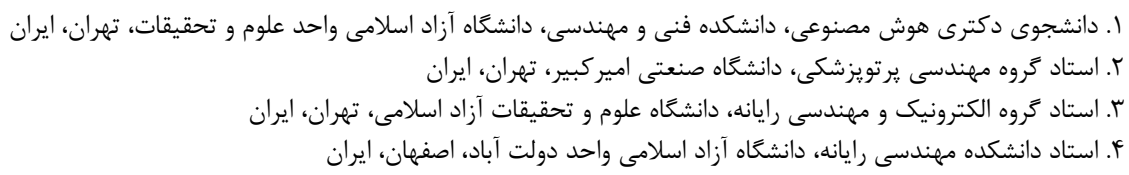

\section{وكيد}

مقدمه: بازشناسى هيجان جندوجهى به واسطه دريافت اطلاعات از منابع حسى (وجههاى) مختلف از يك ويديو داراى جالشهاى فراوانى است و به عنوان روش جديدى براى تعامل طبيعى انسان با رايانه مورد توجه محققان زيادى قرار گرفته است. هدف از اين يثرهش، بازشناسى هيجان به طور خودكار از روى كفتار هيجانى و حالات جهره، مبتنى بر ساز و كارهاى عصبى مغز بود. بنابراين، با توجه به مطالعات صورت كرفته در زمينه مدل هاى الهام كرفته از مغز، يك حارجوب كلى براى بازشناسى هيجان دومداليتى با الهام از عملكرد كورتكس شنوايى و بينايى و سيستم ليمبيك مغز ارائه شود. روش كار: مدل تركيبى و سلسله مراتبى پيشنههادى از دو مرحله يادكيرى تشكيل شده بود. مرحله اول: مدلهاى يادكيرى عميق براى بازنمايى ويزگى هاى بينايى و شنوايى و مرحله دوم: مدل تركيبى يادكيرى هيجانى مغز (MoBEL) بدست آمده از مرحله قبل براى همجوشى اطلاعات شنيدارى_ديدارى. براى بازنمايى ويثگى هاى بينايى به منظور يادكيرى 3D-CNN ارتباط مكانى بين يِكسلها و ارتباط زمانى بين فريمهاى ويدئو از مدل شبكه عصبى يادكيرى عميق استفاده شد. همجنين به منظور بازنمايى ويزّكى هاى شنوايى، ابتدا سيخنال كفتار به تصوير لكَاريتم مل_اسيكتروكرام تبديل شده سيس به مدل يادگيرى عميق CNN براى استخراج ويثگى هاى مكانى_زمانى داده شد. در نهايت، اطلاعات به دست آمده از دو جريان فوق به شبكه عصبى تركيبى MoBEL داده شد تا با در نظر كرفتن همبستخى بين وجه هاى بينايى و شنوايى و همجوشى اطلاعات در سطح ويثگى، كارايى سيستم بازشناسى هيجان را بهبود بخشد. يافته ها: نزخ بازشناسى هيجان در ويديو با استفاده از مدل ارائه شده بر روى پايگاه داده eNterface’05 بطور ميانگين

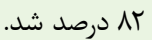
نتيجهََّيرى: نتايج تجربى در پايعاه داده مذكور نشان مى دهد كه كاركرد روش پيشنهادى بهتر از روشهاى استخراج ويزَّى هاى دستى و ساير مدل هاى همجوشى در بازشناسى هيجان است.

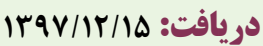

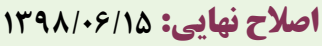

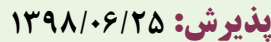

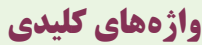

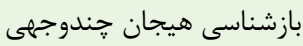
يادكيرى هيجانى مغز

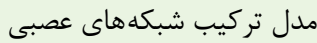

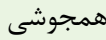
يادكيرى عميق

نويسنله مسئول سعيد ستايشى، استاد كروه مهندسى برتويزشكى، دانشخاه صنعتى اميركبير، تهران، ايران

ايميل:Setayesh@aut.ac.ir

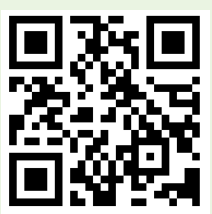

dol doi.org/10.30699/icss.21.4.113

مقلدمه

اطلاعات جندوجهى به عنوان نمونهاى موفق از طرحهاى مدل سازى سلسله مراتبى مىباشد. با اين وجود، بيشرفت مهمى لازم است تا رايانه بتواند در سطح انسان اطلاعات جندوجهى را :بردازش كند. در سالهاى اخير، بازشناسى هيجان جندوجهى به ويزه بازشناسى حالات جهره و هيجان كفتار در بسيارى از كاربردها از جمله: تعامل انسان و رايانه (1)،
انسان يك سيستم هوشمند نهايى مجهز به سنسورهاى جند وجهى است كه قادر به ״ردازش، يادگيرى و پاسخ به محرك هاى جندوجهى مى باشد. به نظر مىرسد انسان، تناظرات نماهاى مختلف را ياد مى گيرد و از آن به همراه ساير روشهاى تركيب اطلاعات جندوجهى در سطوح مختلف انتزاع، استفاده مى كند. اين يك رويكرد ايدهآل براى همجوشى 
مشخصههاى كفتار يیوسته) شامل فركانس كام (ييج)، انرزى و نرخ عبور از صفر (1) (IV و و ويزّكىهاى طيفى (Spectral) شامل فرمنتها، ضرايب (PLP)) و (Mel-frequency Cepstral Coefficient (MFCC)) (Perceptual Linear Prediction روشها از تركيب ويزَّى هاى عروضى و طيفى به همراه طبقهبندهاى

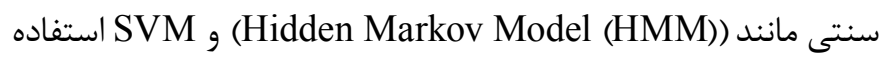

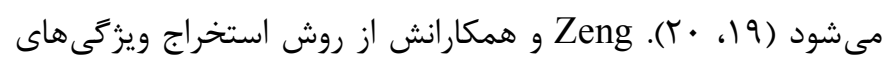

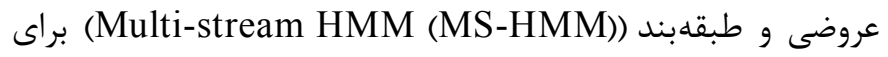
بازشناسى هيجان كفتار در ويديو استفاده كرده است (Iال). Nta-

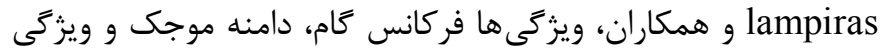
را استخراج كرده و روش همجوشى به نام FFCC

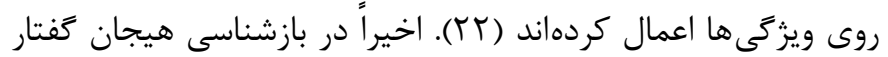

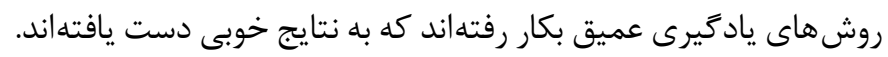
به طور مثال، Zhang و همكاران، ابتدا ويديو را به كليبٍ هايى با مقدار

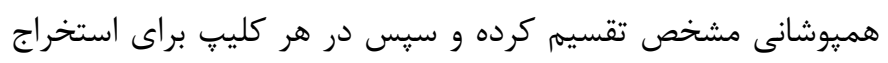
ويزگى ها روش CNN را بر روى تصوير مل_اسيكتروگرام سه كاناله

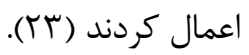
يس از مرحله بازنمايى ويزگى ها، همجوشى جندمداليتى براى ادغام ويزگى ها يا اطلاعات وجه هاى مختلف بينايى و شنوايى براى بازشناسى

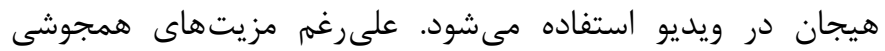
جندوجهى، جالشهاى زير در بازشناسى هيجان وجود دارد: (1)

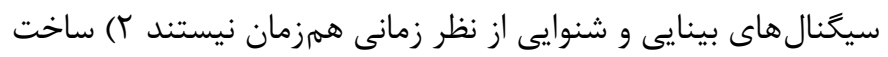

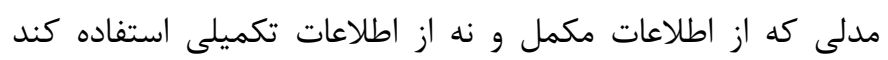

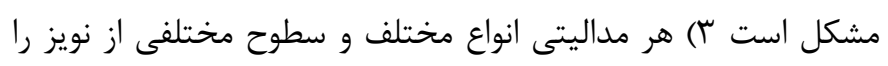

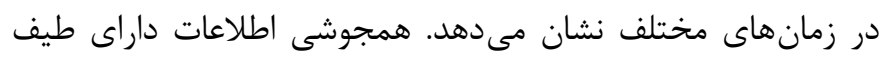
كستردهاى از برنامههاى كاربردى مى باشد كه عبارتند ازئ بازشناسى دهى كفتار صوتى_تصويرى (Yץ)، بازشناسى هيجان جندمداليتى (YQ)، تحليل تصاوير يزشكى (Y)) و بازشناسى رويدادهاى جندمداليتى (YV).

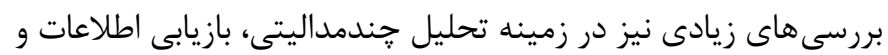

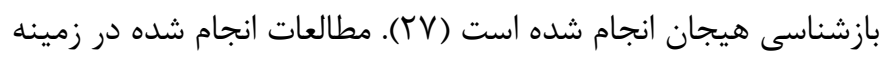

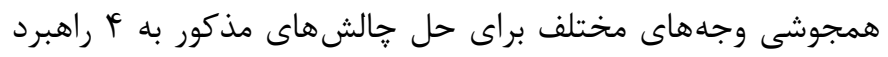

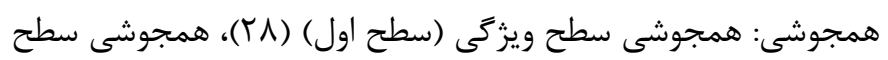

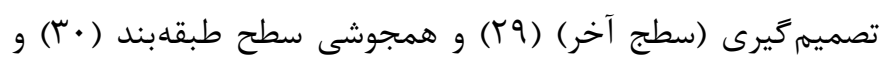

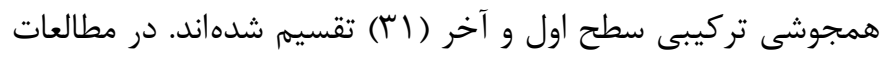
اخير، خط مرز بين بازنمايى جندمداليتى و همجوشى آنى آنها براى مدلهايى مانند شبكههاى عصبى عميق نامشخص مى باشد. در اين شبكهها، يادكيرى بازنماى ويزگى ها با طبقهبندى يا ركرسيون اشياء
بازىهاى رايانهاى (Y)، يادگيرى الكترونيكى (Y)، نظارت بر سلامت

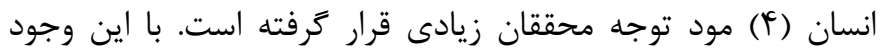

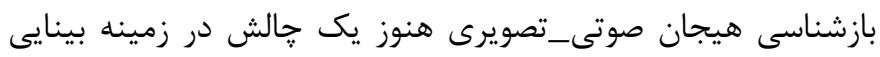

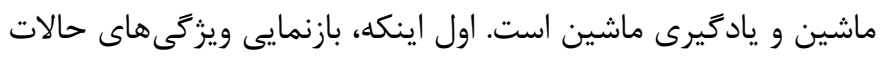

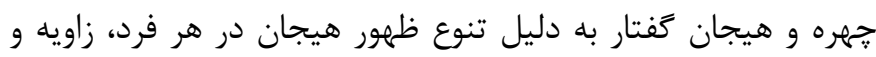

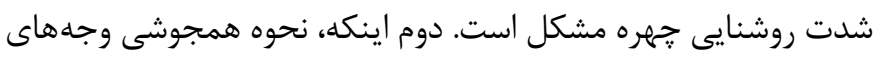

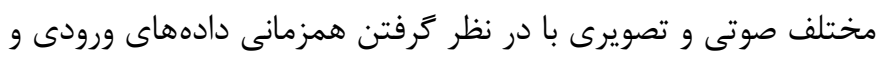
همبستگى موجود در اطلاعات مكان_زمان در ويديو در محاسبه دقت

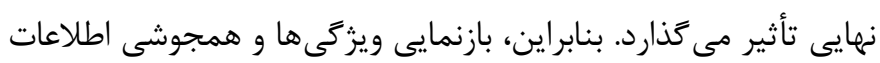
دو مرحله مهمم در بازشناسى هيجان فرآيند ديدارى_شنيدارى مى باشنئ.

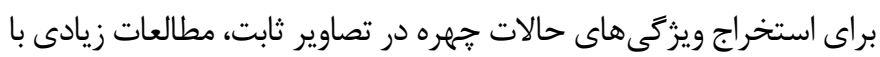

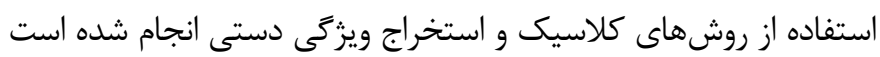

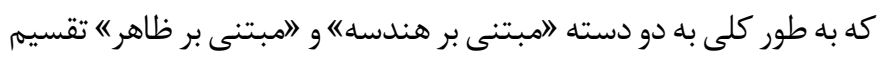

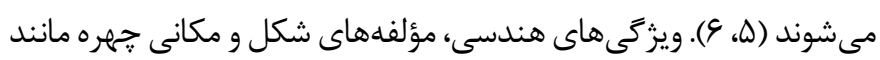

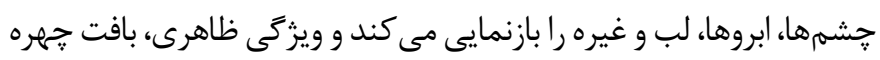

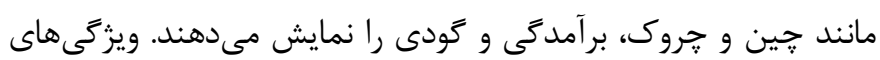

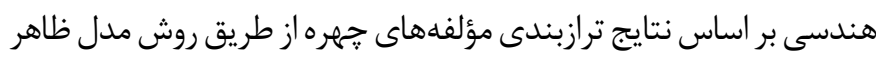
فعال (Active Appearance Model (AAM) بدست مى آيند (ه). و و همكاران از مدل شكلى كه به وسيله \ه ن نقطه برجسته در جهره

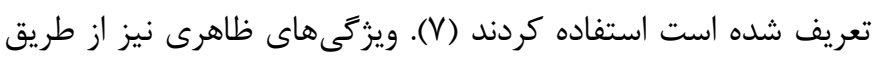

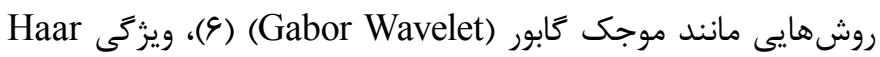

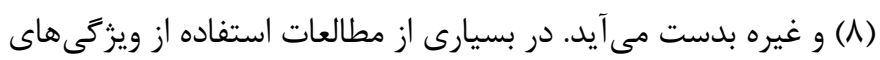

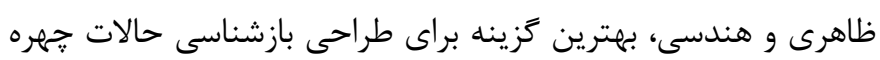

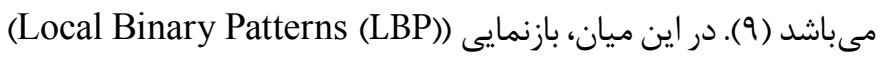

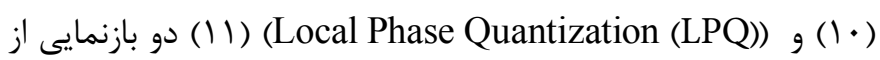
روش هاى استخراج ويزگى مبتنى بر ظاهر مى باشند. در سال هاى اخير،

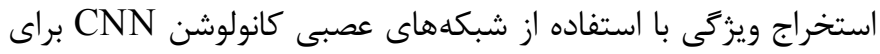
بازنمايى حالات جهره در تصاوير ثابت و يويا مورد استفاده قرار كرفته

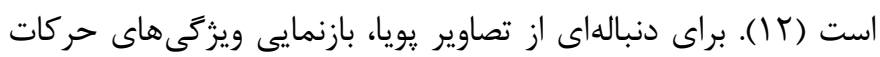

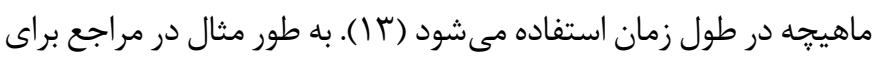

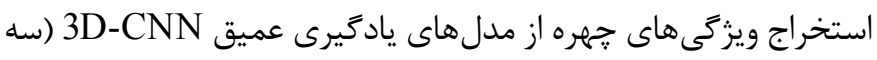
بعدى) و CNN-RNN با در نظر كرفتن توالى مكان_زمان بروز هيجان در جهره در ويديو استفاده مىشود (أl ا، لها (1).

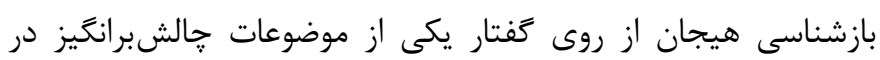

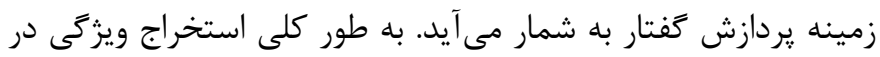

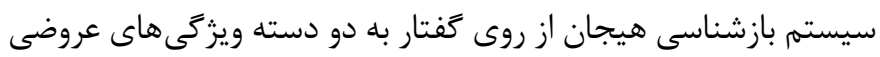
و طيفى تقسيم مىشوند. ويزگگ هاى عروضى (Prosodic) (يا به عبارتى 


\section{روش كار} از آنجا كه ساختار مدل يُيشنهادى الهام كرفته شده از مدل فيزيولوزى

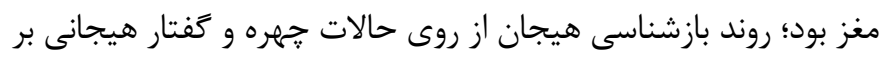
اساس مسير استخراج ويزگى در قشر بينايى و شنوايى شبيهسازى شد.

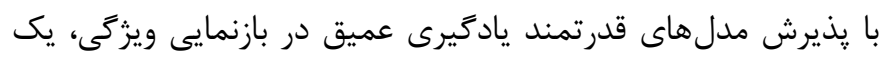
مدل همجوشى MoBEL از طريق همجوشى ويزگ هـى هاى ياد كرفته شده

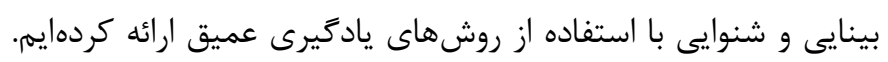

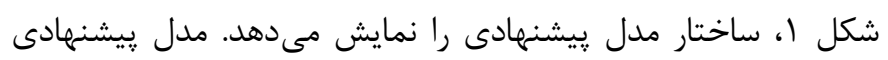

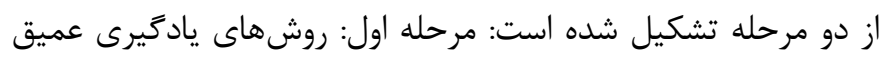

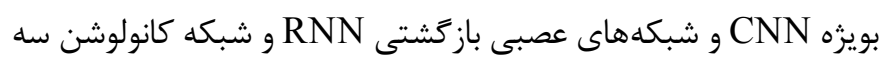
بعدى 3D-CNN براى بازنمايى ويزگ هاى ها در سطح بالاتر اعمال مى شوند.

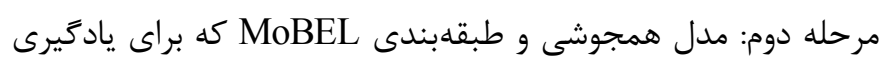

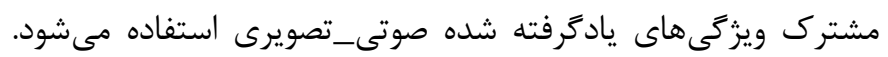

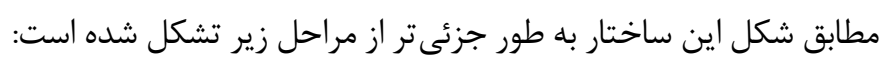

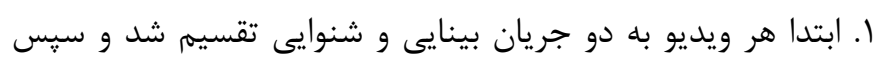

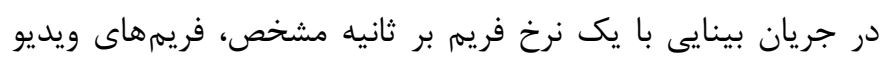
استخراج ترديد.

r. در جريان بينايى براى دنبالهاى از تصاوير ابتدا با استفاده از عمليات

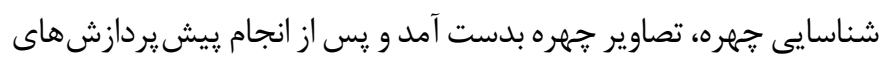

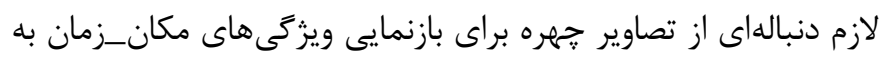
مدل شبكه عصبى 3D-CNN داده شد.

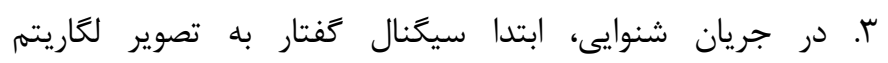

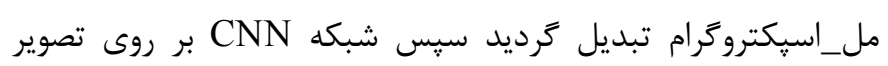
بدست آمده اعمال شد.

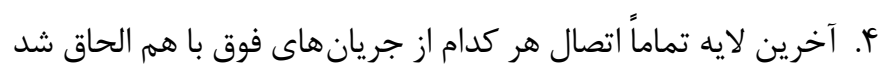

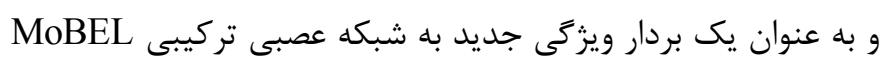

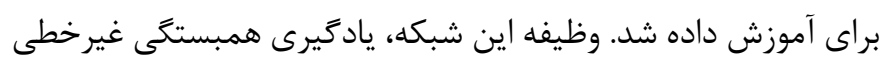

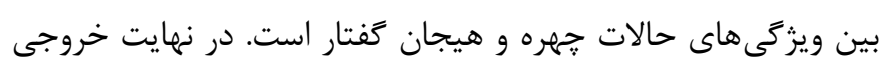

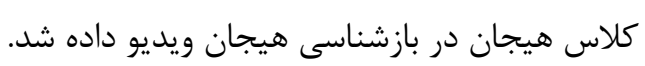

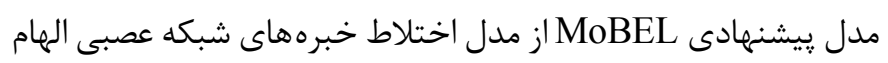
كرفته شده است با اين تفاوت كه در اينجا اختلاط خبرهها (Mixture دإل (Mixture of Experts (MoE)) يايه راهبرد تقسيم و حل استوار است. به صورتى كه مجموعه آموزش

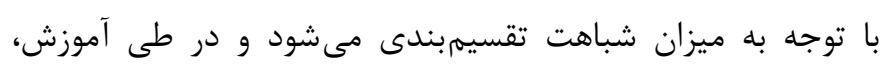
طبقهبندهاى مختلف سعى مى كنند تا قسمتهاى مختلفى از فضاى مئى

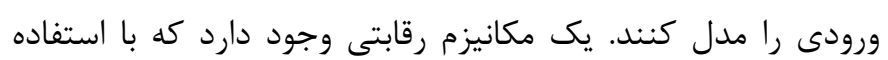
از يك شبكه ميانجى، طبقهبندها را به صورت محلى ماهر مى نمايد.
همخوانى دارد (Tr). اكرجه اين روشها كارايى بالايى را در همجوشى

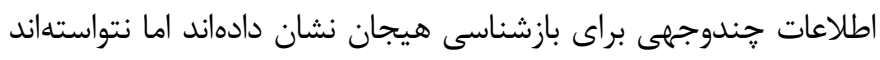

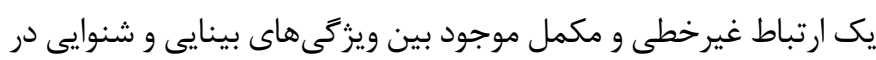

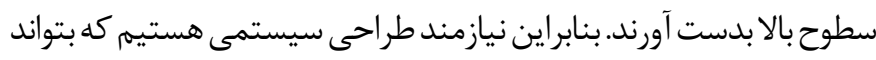

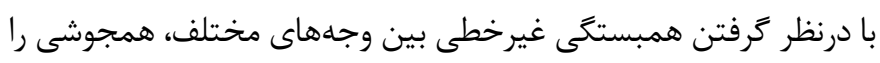
در سطح بالاى ويزگى انجام دهد. از آنجايى كه در مغز انسان، سيستم

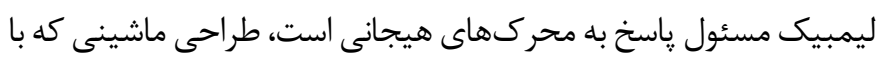

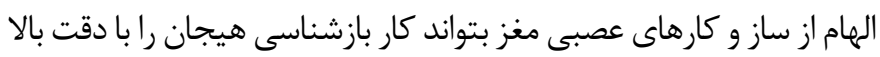

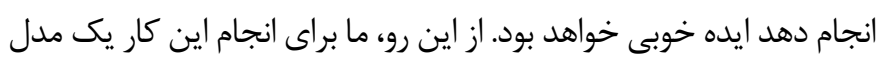

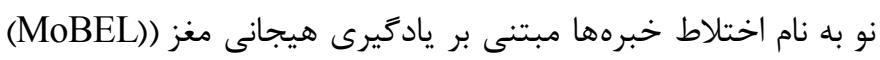
Mixture of Brain Emotional Learning جامعترين مدلى كه الهام گرفته از سيستم ليمبيك مغز يستانداران

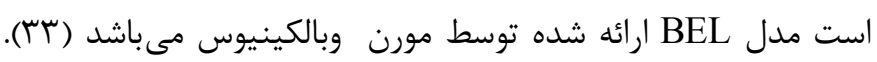

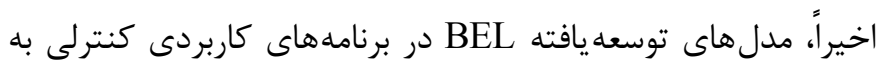

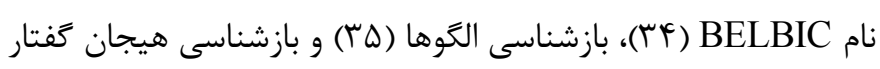

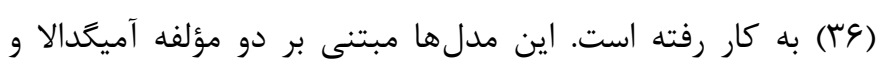

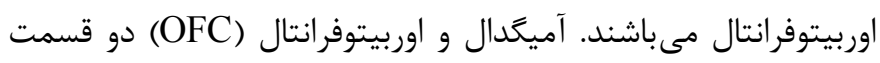

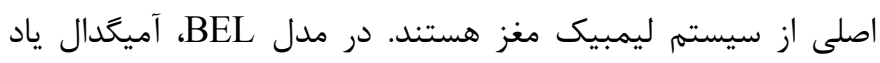

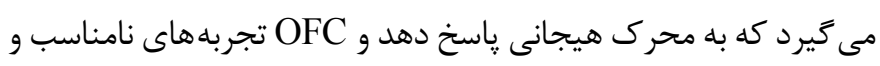

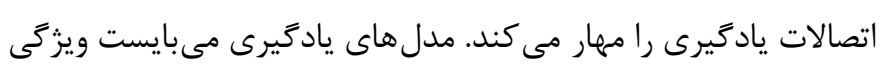

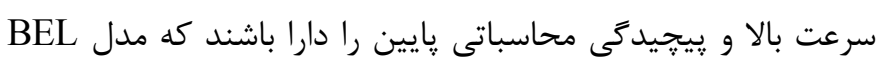

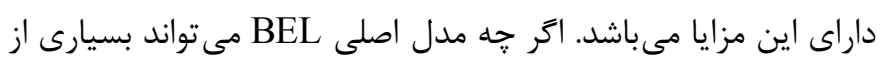

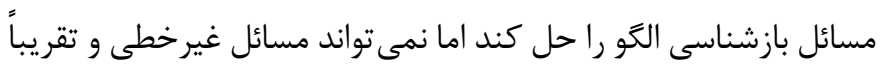
درجه n بيتى را حل كند. براى غلبه بر اين مشكل، لطفى و همكاران،

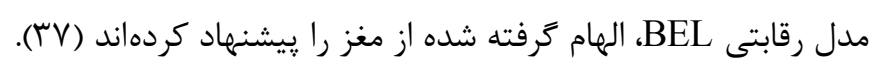

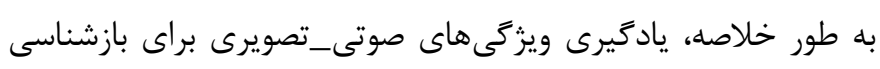

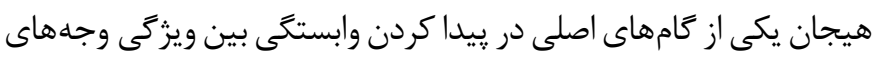
مختلف مى باشد. مطالعات قبلى بيشتر بر روى ويزَى هاى دسى دستى تمركز

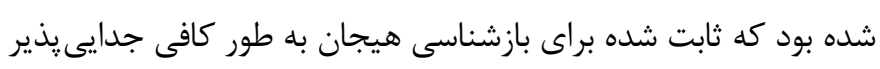

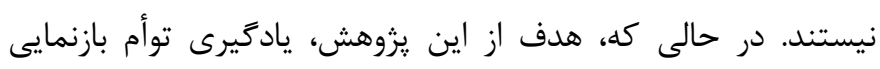

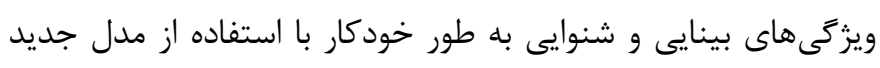

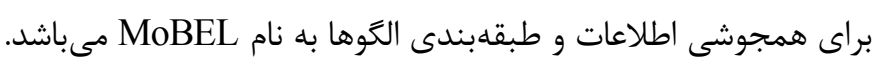

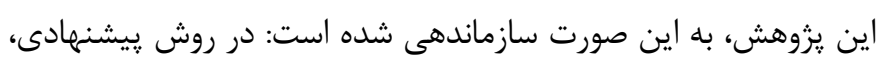

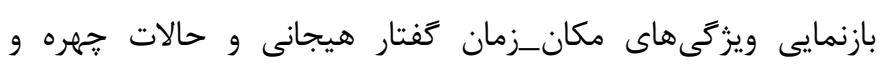

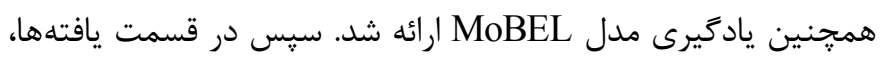

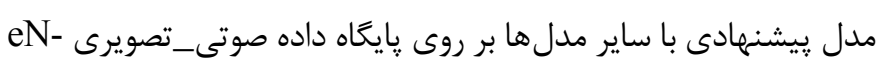
terface 


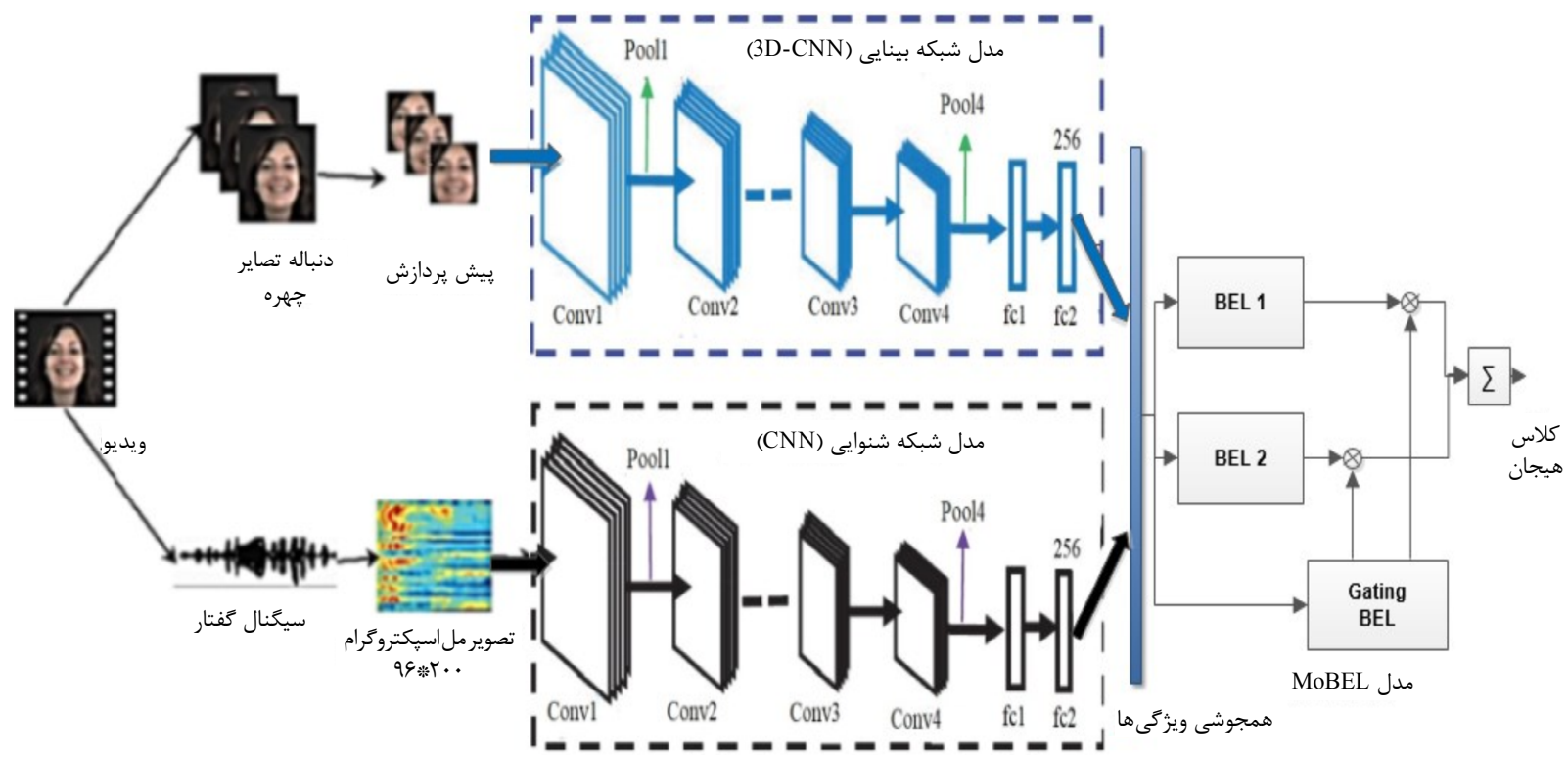

شoBEL شل ا. ساختار مدل يِشنهادى. بازشناسى هيجان از روى ويديو با استفاده از ويزگى هاى بينايى و شنوايى و اعمال مدل

تماماً اتصال (FC) مى باشد كه آخرين لايه FC داراى عهـ نورون و لايه Softmax

\section{بازنمايى ويزَى هيجان كَفتار}

همانطور كه قبلتر توضيح داده شد؛ براى بازنمايى ويزّىى هيجان

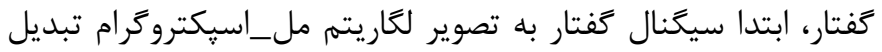
شد. اسيكتروگرام يك بازنمايى تصويرى از شدت سيكنال صوت در

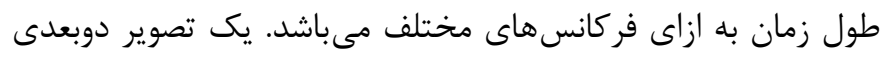

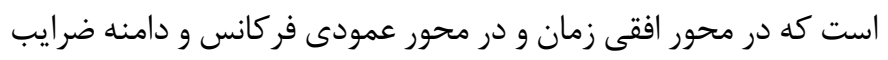
فركانس در يك زمان مشخص با شدت رنگ در تصوير مشخص مى شود. از آنجايى كه CNN يك روش قدرتمند و مقاوم در استخراج ويزگى هاى متمايز براى تصاوير و ويديو مىباشد، تبديل سيخنال يك بعدى صوت

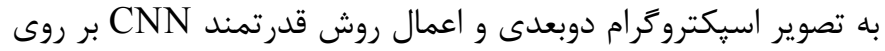
آن ايده جالبى مى تواند باشد. تصوير لكَاريتم مل_اسيكتروگرام از طريق

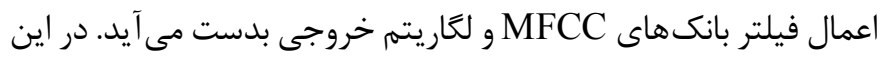
يزوهش، ابتدا سيخنال هاى صوتى را به طول ₹ ثانيه در نظر ترفته شد.

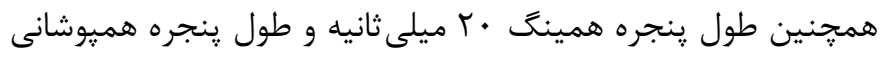
• إ ميلى ثانيه در نظر ترفته شد.

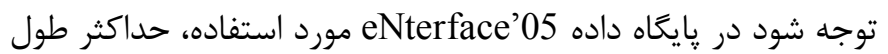
كفتار \& ثانيه است. اگر طول مدت زمان كفتار كمتر از \& ثانيه باشد با استفاده از روش Zero padding به اندازه اختلاف زمانى با طول ع ثانيه، تعدادى صفر به ابتداى ماتريس كفتار اضافه نموديم و اگر هم
شواهدى وجود دارد كه نورونهاى رقابتى در مغز از مجموعهاى از

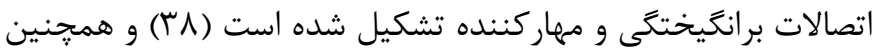
مدل MoE از قشر حافظه انجمنى مغز الهام گرفته شده است كه مى تواند اطلاعات منابع حسى مختلف را ادغام كند.

بازنمايى ويزگى حالات جهره در اين مدل براى بازشناسى حالات جهره در تصاوير ويدئو از شبكه

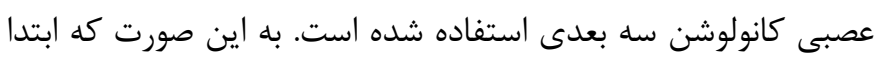

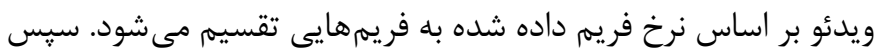
عمليات پيش يردازش بر روى فريمهاى بدست آمده از ويدئو اعمال مىشود. اين عمليات شامل آشكارسازى جهره، ترازبندى جهره و تغيير

$$
\text { اندازه تصوير مى باشد. }
$$

در انتها هر نمونه ويديو ورودى در قالب يك بردار جهار بعدى شامل دنبالهاى از تصاوير جهره در فريمهاى هر ويدئو به اندازه fl فريم

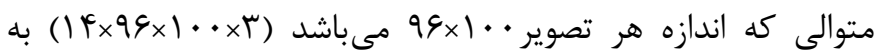

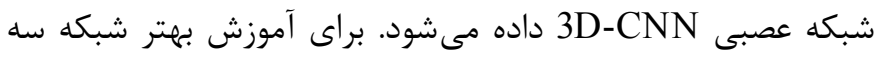
بعدى 3D-CNN از آموزش اوليه اين شبكه براى مقداردهى اوليه

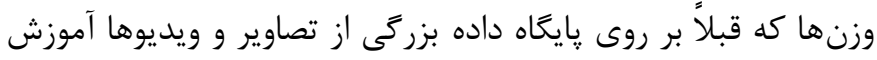
داده شده بود به نام C3D-Sports-1M استفاده شده است. اما براى في جلوگيرى از Overfitting شبكه و مواجه نشدن با خطاى كمبود حافظه، لايههاى آخر شبكه را حذف كردهايم. به اين ترتيب، شبكه 3D-CNN داراى ^ لايه كانولوشن، ه لايه Max-pooling و r لايه 
و خروجى شبكه ميانجى به صورت زير تابعى از الكوى ورودى و وزن هاى يادگيرى است. (رابطه بـ)

$g_{i}=\frac{\exp \left(O_{g i}\right)}{\sum_{j=1}^{N} \exp \left(O_{g i}\right)}$

با تعريف رابطه فوق براى gi مجموع وزن هاى تخصيص داده شده به هر كدام از طبقهبندهاى يايه برابر با يك است. اخر اختلاف خروجى هر كدام از طبقهبندهاى يايه با خروجى مطلوب كمتر باشد يعنى خطاى آن كمتر است و در نتيجه وزن g g gيشترى به آن اختصاص داده مىشود. در شبكه ميانجى از يك مدل BEL (شامل r آميدلا و r اوربيتوفرانتال به منظور ايجاد دو خروجى) با دو وزن خروجى hi مقدار خروجى مطلوب BEL مقده است. در اين مدل از طريق رابطه \& تعريف مىشود. اين عبارت را مىتوان عمليات Softmax

$h_{i}=\frac{\mathrm{g}_{i} \exp \left(-\frac{1}{2}\left(t-E_{i}\right)^{T}\left(t-E_{i}\right)\right)}{\sum_{j} \mathrm{~g}_{i} \exp \left(-\frac{1}{2}\left(t-E_{i}\right)^{T}\left(t-E_{i}\right)\right.}$

كه t مقدار خروجى مطلوب و E خروجى هر كدام از طبقهبندهاى يايه است. در اختلاط خبرهها با تعريف تابع خطا يا هزينه و اعمال گراديان نزولى روشى براى آموزش با ناظر در هر كدام از طبقهبندهاى يايه ارائه شد. رابطه ه تابع خطاى كل سيستم بود.

$e=\sum_{i} g_{i}\left\|y-E_{i}\right\|^{2}$

و خروجى هر كدام از طبقهبندهاى يايه بر اساس رابطه \& و محاسبه شد:

$E_{i}=f\left(f_{a m g}\left(\sum_{j=1}^{n} v_{j} p_{j}+v_{n+1} p_{t h}\right)-f_{o f c}\left(\sum_{j=1}^{n} w_{j} p_{j}\right)\right)$

$p_{t h}=\max \left(p_{j}\right) . \quad j=1 . \ldots n$

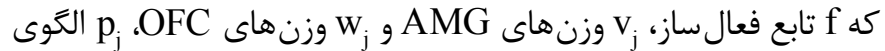
ورودى و pth بيشترين مقدار ورودى كه به صورت باياس عمل مى كند، است. بر اساس روابط بالا و مشتق خطا نسبت به هر كدام از وزنهاى و AMG روابط ^ و و 9 محاسبه شد. $\Delta v_{i j}=-\gamma v_{i j}+\alpha h_{i} \max \left(t-E_{i} .0\right) p_{j}$. for $i=1.2$ for $j=1 . \ldots . n(\Lambda)$ $\Delta w_{i j}=\beta h_{i}\left(E_{i}-t\right) p_{j}$

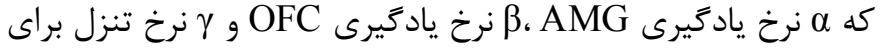
مومنتوم بود. همجنين در شبكه ميانجى اصلاح وزنهاى AMG و
بيشتر از f ثانيه بود فقط \& ثانيه ابتداى گفتار را انتخاب كرديم. سيس فيلتر مل_اسيكتروگرام بر روى هر كدام ينجرههاى همينگ از طريق محاسبه رابطه ا اعمال شد:

$f_{m e l}(f)=2595 \log _{10}\left(1+\frac{f_{H Z}}{700}\right)$

براى هر كدام از سيگنال هاى صوتى يس از اعمال رابطه فوق، وج ضريب

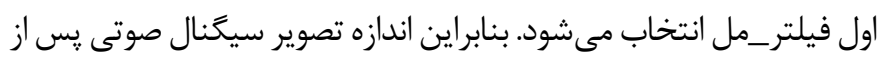

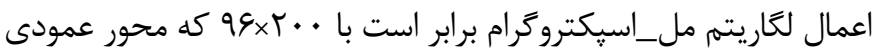
نشاندهنده ضرايب فيلتر مل و محور افقى نشاندهنده طول زمان كه به صورت رابطه زير محاسبه شد: طول ينجره همينگ/طول مدت زمان كفتار=محور افقى. در مرحله آخر، شبكه CNN براى استخراج ويزگى هاى كفتار بر روى تصاوير بدست آمده از سيخنال هاى صوتى اعمال شد.

\section{MoBEL مدل بيشنههادى} ساختار اختلاط شبكههاى عصبى كه زيرمجموعه اختلاط خبرهها است از جند خبره و يك شبكه ميانجى تشكيل شده است. شبكه ميانجى دو وظيفه دارد يكى اينكه فضاى ورودى را به صورت هوشمندانه بين طبقهبندها تقسيم كند. دوم اينكه با توجه به توانمندى طبقهبند براى طبقهبندى صحيح الخوى ورودى يك وزن به آن تخصيص دهد. همزمان با يادگيرى طبقهبندها، شبكه ميانجى ياد مى گيرد كه جَّونه وزن مربوط به نظر هر طبقهبند رالي به صورت تابعى از الكوى ورودى محاسبه كند. به عبارتى با دو مدل از يادَيرى مواجه هستيم: يكى يادَيرى با ناظر در درون هر خيره و ديگرى يادگيرى بدون ناظر كه در شبكه ميانجى انجام مى شود.

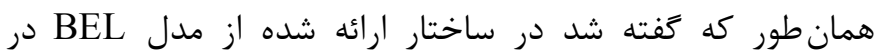
خبرهها و شبكه ميانجى استفاده شد. در شكل r، دو خبره و يك شبكه ميانجى نشان داده شده است. فرض كنيد كه

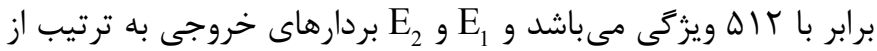

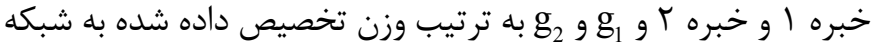
BEL1 از احتمال رِين آن است كه شبكه أlم بتواند الكوى p را به درستى طبقهبندى كند. تعداد نورون هاى لايه خروجى شبكه ميانجى با تعداد خبرهها برابر است. y نيز خروجى نهايى مدل است. خروجى نهايى سيستم y به صورت رابطه r محاسبه شد:

$y=\sum_{i} E_{i} g_{i} . \quad i=1 . \ldots . N$ 
كه $\alpha$ نرخ يادكيرى AMG، نرخ ياد ميرى OFC در شبكه ميانجى OFC به صورت روابط • او لا است. هستند. به اين ترتيب در فرآيند آموزش، به ازاى هر ورودى خبرهها با براي هم در رقابت هستند و شبكه ميانجى بر اساس خطاى هر خبره برنده

$$
\text { را انتخاب مى كند. } \quad \Delta w_{g j}=\beta\left(g_{i}-h_{i}\right) p_{j}
$$

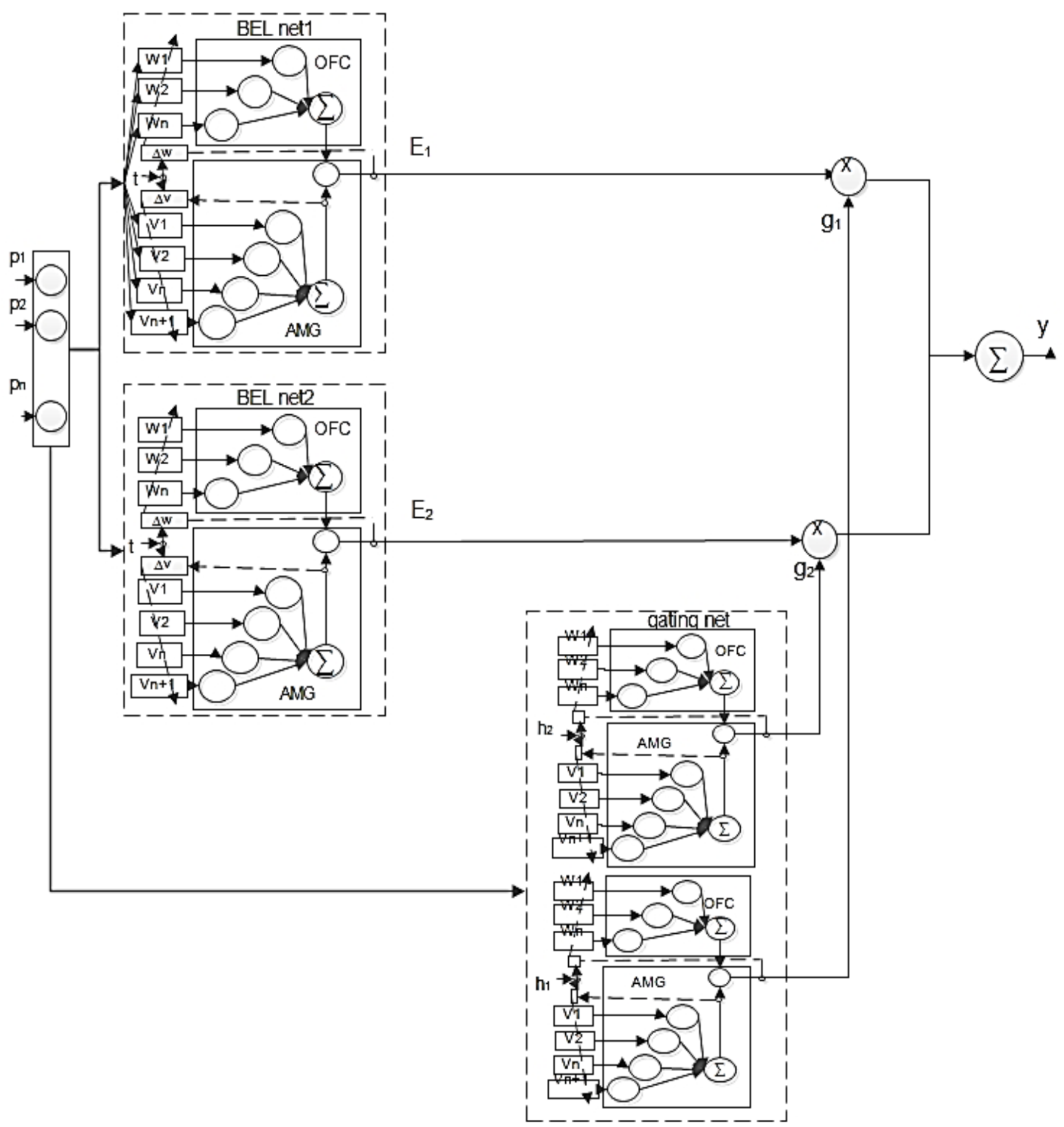

شكل r. ساختار مدل بيشنهادى MoBEL. از دو خبره BEL و يك شبكه ميانجى BEL تشكيل شده است 
ميانجى BEL به صورت بدون نظارت همزمان آموزش ديدند. آزمايش بازشناسى هيجان بر روى پايگاه داده eNterface'05 با در نظر خرفتن

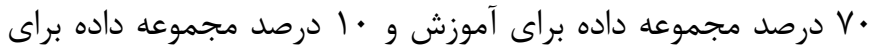

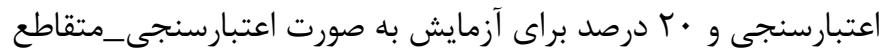
انجام شد و ميانيخن ه بار اجرا كزارش شده است. (Cross validation)

\section{نتايج بازشناسى حالات جهره}

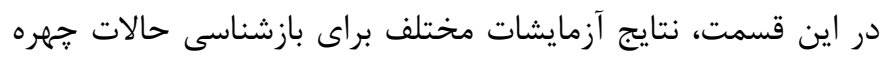

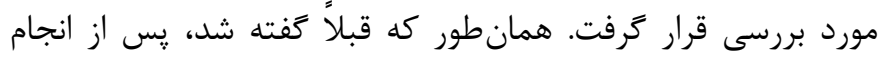
عمليات پِيش يردازش، دنبالهاى از تصاوير جهره بدست آمد. به ازاى

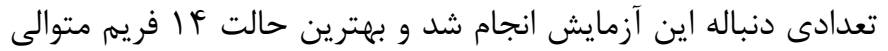

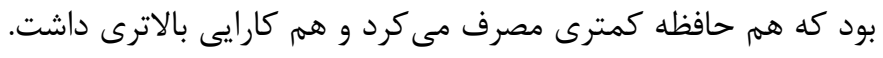

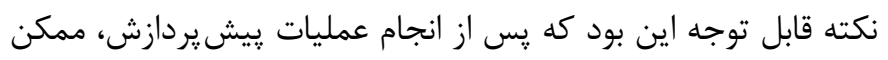

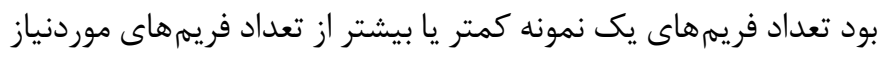

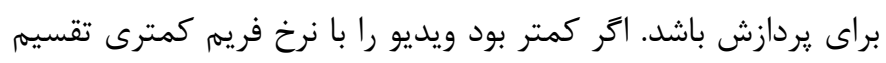

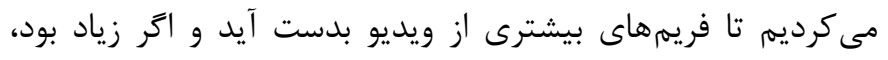
ضرايبى از فريمها را انتخاب مى كرديم. پس از اعمال مدل 3D-CNN بر روى دنبالهاى از تصاوير جهره به منظور بازشناسى حالات حهرهاب

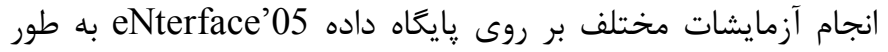
متوسط دقت بازشناسى هيجان جهره به ازاى تمام كلاسها بوع درصد بدست آمد. در جدول ا، ماتريس درهمريختكى بازشناسى حالات جهره

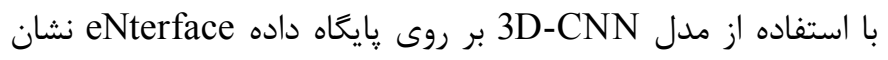

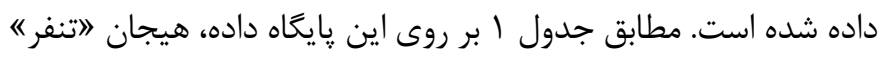

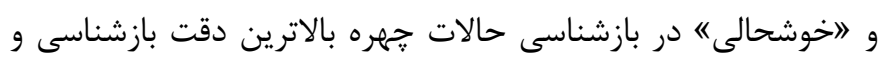

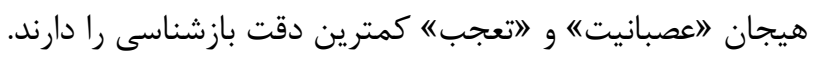

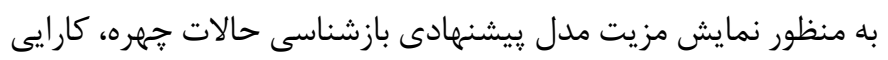
اين مدل با ساير روشهايى كه از يايخاه داده eNterface’05 استفاده

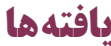

به منظور بررسى و ارزيابى مدل پيشنهادى در بازشناسى هيجان صوتى_تصويرى، ساختار مدل ييشنهادى را بر روى پاييگاه داده

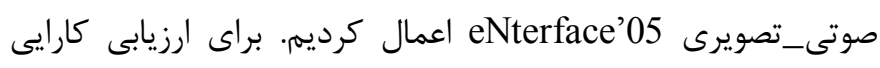

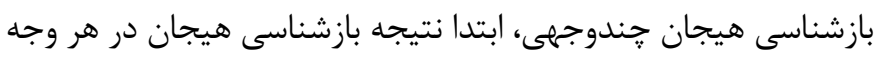

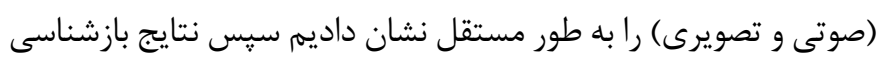

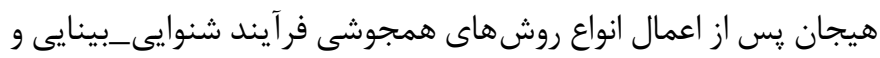
مقايسه آنها با مدل بيشنهادى همجوشى ران إنشان داده شد. مطابق شكل ا، مدل ييشنهادى از دو مرحله تشكيل شده بود. جزئيات ييادهسازى مدل هاى يادگيرى عميق 3D-CNN و CNN به ترتيب مدل شنوايى و بينايى به صورت زير بود: اندازه هر دسته (Batch)

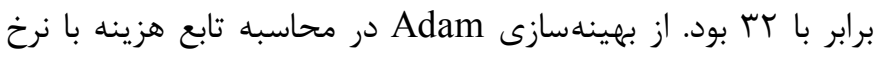

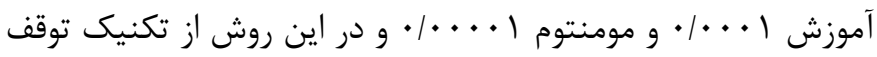
زودهنگام در زمان آموزش استفاده شد. تعداد دفعات تكرار در مرحله

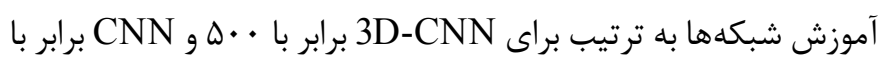

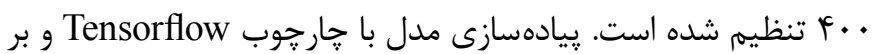
روى ماشينى با مشخصات GPU NVIDIA GTX با ^ گيخ حافظه انجام شد. براى آموزش شبكه عصبى MoBEL از دو شبكه عصبى خبره بر קايه مدل BEL و يم شبكه ميانجى بر پايه BEL استفاده

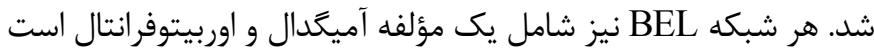

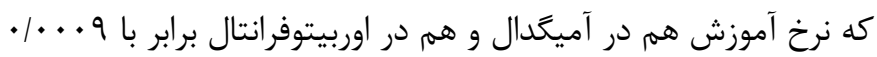

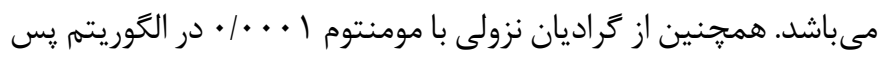

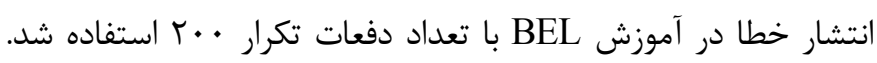

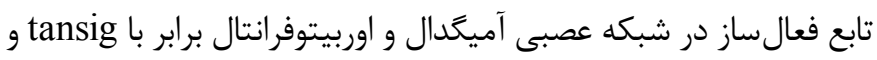

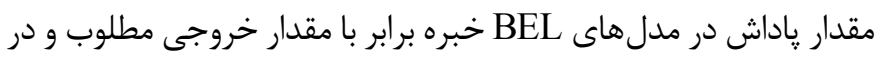
شبكه ميانجى برابر با مقدار خروجى مطلوب h مطابق رابطه است (1). بنابراين شبكههاى خبره BEL به صورت يادگيرى با نظارت و شبكه

جدول ا. ماتريس درهمريختخى بازشناسى حالات جهره با استفاده از 3D-CNN بر روى پإيخاه داده eNterface-05 (درصد)

\begin{tabular}{|c|c|c|c|c|c|c|}
\hline تعجب & ناراحتى & خوشحالى & ترس & تنفر & عصبانيت & \\
\hline$\Delta$ & 1. & r & 10 & r & FV & عصبانيت \\
\hline r & $\Delta$ & . & $\Delta$ & $\wedge \varepsilon$ & $r$ & تنفر \\
\hline 1. & IV & $\Delta$ & $\Delta \Delta$ & v & v & ترس \\
\hline 1. & $\Delta$ & sV & $\Delta$ & ir & r & خوشحالى \\
\hline 1. & QV & r & If & r & $\Delta$ & ناراحتى \\
\hline fr & 10 & 1. & IV & $\Delta$ & 1. & تعجب \\
\hline
\end{tabular}




\section{نتايج بازشناسى هيجان كفتار} ابتدا سيكنال كفتار تبديل به تصوير مل_اسيكتروكرام به اندازه

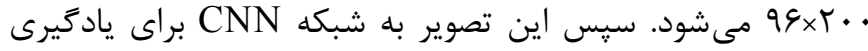

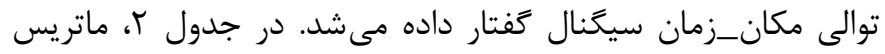

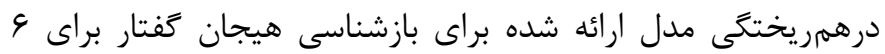

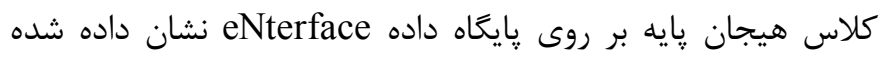
است. به طور متوسط يُ از ه بار اجرا، ميانكَين دقت بازشناسى هيجان كفتار با استفاده از مدل CNN، وV/V درصد بدست آمد. مطابق جدول س، حالت هيجان "اناراحتى" و "عصبانيت) بالاترين و "تنفر"

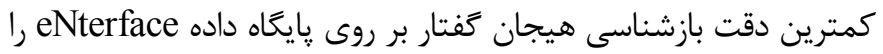
داشتند. براى نمايش مزيت مدل يِيشنهادى بازشناسى هيجان كفتار، كارايى آن با ساير روشها مورد مقايسه قرار كرفت. نتايج اين مقايسه در جدول

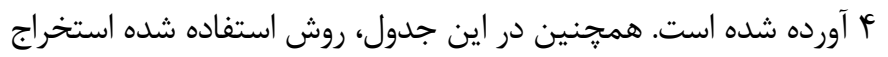

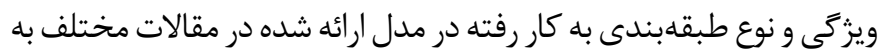

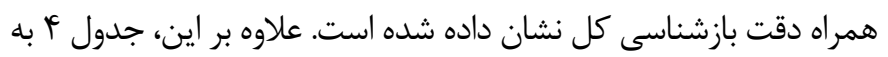

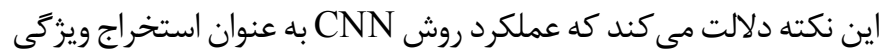
بهتر از عملكرد ساير روشهاى استخراج ويزگى دستى مانند استخراج ويزگى هاى عروضى و طيفى كفتار به صورت دستى مىباشد.
كردهاند مورد مقايسه قرار گرفت. در جدول r نتيجه اين مقايسه نشان

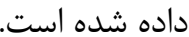

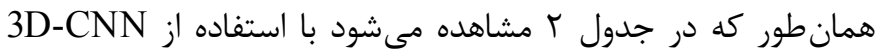
دقت بازشناسى حالات جهره بسيار بهتر از ساير روشهاى استخراج

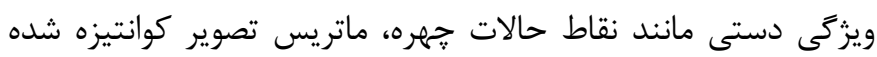

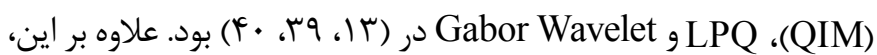
مدل يادكيرى عميق ديخرى براى بازشناسى حالات جهره به نام CNN RNN ارائه شد و بر روى باياتاه داده موجود مورد بررسى و ارزيابى قرار كرفت. با وجود اينكه در مقايسه با مدل 3D-CNN يارامترهاى كمترى داشت و حافظه كمترى مصرف مى كرد اما دقت بازشناسى آن كمتر بود.

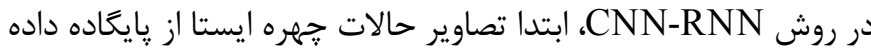

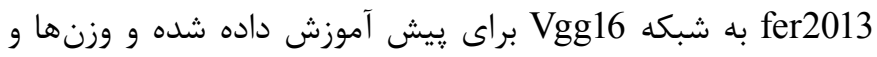
يار امترهاى شبكه ذخيره مىشدند، سيس فريمهاى تصاوير حالات جهره

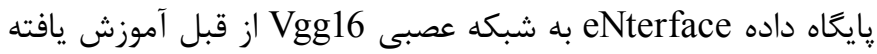

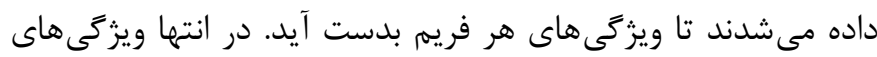

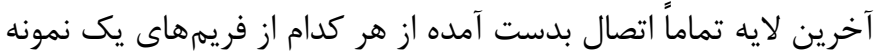
ويدئو در ماتريس دو بعدى ذخيره مىشدند كه اين ماتريس در مرحله

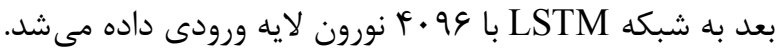

جدول r. مقايسه دقت بازشناسى حالات جهره بين روش هاى مختلف و مدل يِيشنهادى به ازاى \& كلاس در پايغاه داده eNterface’05

\begin{tabular}{|c|c|c|}
\hline مراجع & بازنمايى ويثزى حالات جهره & 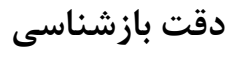 \\
\hline Mansoorizadeh و همكاران (rו) & نقاط برجسته حالات جهره & 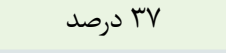 \\
\hline Bejani & QIM & 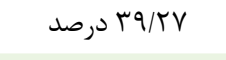 \\
\hline Zhalephpour و همكاران (૧ (ז) & LPQ & | \\
\hline مدل پِيشنهادى اول & CNN-RNN & 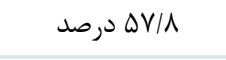 \\
\hline مدل بيشنهادى ما & $3 \mathrm{D}-\mathrm{CNN}$ & r ب درصد \\
\hline
\end{tabular}

جدول r. ماتريس درهمريختكى بازشناسى هيجان گفتار با استفاده از مدل CNN بر روى پايخاه داده eNterface-05 (درصد)

\begin{tabular}{|c|c|c|c|c|c|c|}
\hline تعجب & ناراحتى & خوشحالى & ترس & تنفر & عصبانيت & \\
\hline$\Delta$ & r & $r$ & 1 & v & $\wedge 1$ & عصبانيت \\
\hline 1. & v & v & 9 & $\Delta \Delta$ & ir & تنفر \\
\hline$\Delta$ & if & if & $\Delta q$ & 9 & r & ترس \\
\hline 1. & r & 99 & $\Delta$ & $r$ & ir & خوشحالى \\
\hline 1. & v. & 1 & 1. & $\Delta$ & $\Delta$ & ناراحتى \\
\hline$q r$ & $\Delta$ & 10 & $r$ & 1. & $\Delta$ & تعجب \\
\hline
\end{tabular}




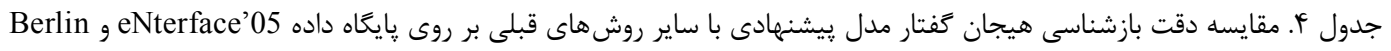

\begin{tabular}{|c|c|c|c|}
\hline دقت (درصد) & ويثَى هاى صوتى & مراجع & يايگًاه داده \\
\hline r pr & عروضى، LDA & Mansoorizadeh و همكاران (rا) & \multirow{6}{*}{ eNterface'05 } \\
\hline$\Delta V$ & MFCC & Sahoo و همكاران (f) & \\
\hline GT/V & عروضى+ طيفى & Zhang و همكاران (Fr) & \\
\hline$\Delta F / q$ & عروضى + MFCC & (f) و همكاران (fejani & \\
\hline$V r / 9$ & MFCC-RASTA-PLP & Zhalehpour & \\
\hline$q V / V$ & CNN +مل اسيكتروگرام & مدل پيشنهادى & \\
\hline $9 \Delta / \Delta$ & CNN + اسيكترو گرام & Badshah و همكاران (rॅץ) & \multirow{4}{*}{ Berlin } \\
\hline VI & 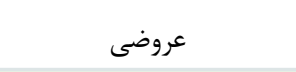 & Mansoorizadeh و همكاران (Fץ) & \\
\hline 99 & عروضى + MFCC & Farhoudi & \\
\hline$V \psi / \Delta$ & CNN + مل اسيكتروگرام & مدل קيشنهادى & \\
\hline
\end{tabular}

همجوشى سطح تصميم گيرى در اين آزمايش، خروجى نهايى به دست آمده از دو فرآيند شنيدارىــ ديدارى با يكديگر تركيب مىشوند. براى همجوشى در سطح تصميم گيرى، انواع روشهاى قواعد تركيب مورد آزمايش قرار گرفته است كه عبارتند از: كمترين، بيشترين، ميانگين و حاصل ضرب. نتايج اين آزمايش در جدول ه نشان داده شده است. مطابق جدول ه، قانون تركيب "حاصل ضرب" بالاترين دقت بازشناسى را دارد. زيرا كه حاصل ضرب با ضرب امتياز خروجى وجه هاى مختلف، بيشينه امتياز كلاس را به دست مى آورد.

\section{همجوشى سطح بالاى ويثزى}

در اين آزمايش كه مدل ييشنهادى و محور اصلى و نوآورى يروهش بود از مدل بهبود يافته و تركيبى BEL به نام MoBEL (مطابق شكل I) براى همجوشى ويزگَى هاى بدست آمده از حالات جهره و هيجان گفتار استفاده شد. به اين صورت كه در مسير بينايى، دنبالهاى از تصاوير
علاوه بر اين، ما مدل CNN را بر روى یايگاه داده Berlin نيز اعمال كردهايم و نتيجه عملكرد اين مدل را با نتايج كارهاى قبلى مانند

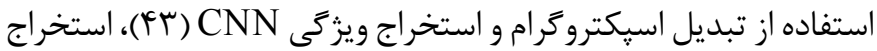
ويزگگ هاى عروضى (FF)، تركيب استخراج ويزگى هاى عروضى و ضرايب MFCC و استفاده از مدل BEL براى بازشناسى هيجان كفتار در كار قبلى (צس) مورد مقايسه قرار داديم. مطابق جدول عا، ثابت شده است كه هم كارايى لكاريتهم مل_اسيكتروگرام بهتر از اسيكتروگرام است و هم مدل CNN كه يك مدل شناخته شده در دستهبندى تصاوير است قادر به يادگيرى همبستخى زمان_مكان سيخنال گفتار بود و كارايى آن بهتر از ساير روش هاى قبلى است.

نتايج همجوشى اطلاعات در اين :زيوهش، عملكرد مدل ييشنهادى همجوشى شبكه عصبى MoBEL و همجوشى سطح تصميم گيرى (آخر) مورد مقايسه و ارزيابى قرار گرفت.

جدول ه. مقايسه دقت بازشناسى هيجان مبتنى بر همجوشى سطح تصميمَيرى بين روش هاى مختلف تركيب قواعد (درصد)

\begin{tabular}{|c|c|c|c|c|c|}
\hline حاصل ضرب & ميانگَين & 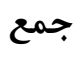 & كمتر ين & بيشترين & انواع روش هاى قواعد تركيب \\
\hline$V F / \mu$ & $V I / 4$ & $V I / 4$ & vi & GN/9 & دقت بازشناسى هيجان \\
\hline
\end{tabular}


در اين يزوهش از تركيب شبكههاى عصبى تركيبى مبتنى بر اختلاط خبرهها كه در هر خبره يك مدل BEL بود؛ براى افزايش كارايى سيستم استفاده شد. براى نشان دادن مزيت استفاده از مدل اختلاط خبرهها مبتنى بر مدل BEL، اين مدل با طبقهبندهاى ديكر مورد مقايسه قرار

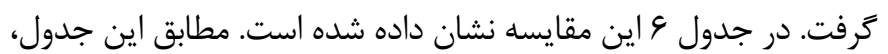

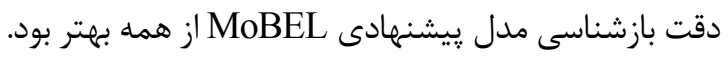

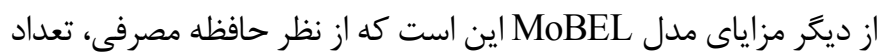
يارامترهاى آموزش و سرعت يردازش بسيار كارامدتر از ساير طبقهبندها از

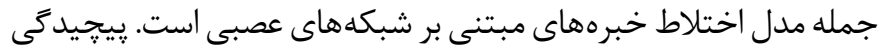

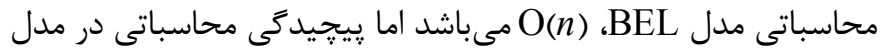

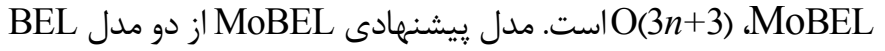

جهره به شبكه 3D-CNN داده مىشدند و يس از اعمال لايههاى

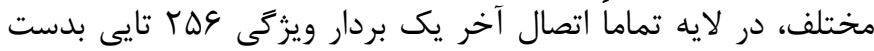

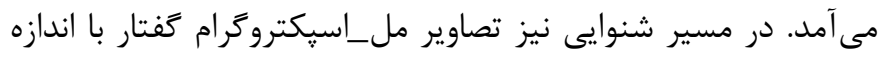

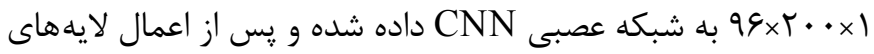
مختلف يك بردار ويزگ

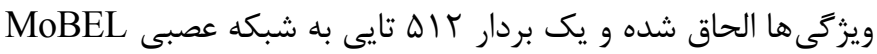

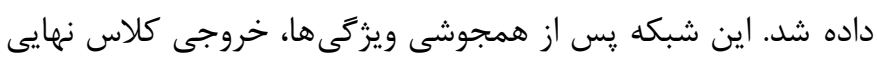

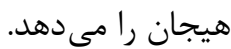
از آنجا كه همجوشى ويزگى هاى بدست آمده از دو جريان شنيدارى_ ديدارى يك مسأله با ييجيدگى بالا بود و ارتباط وجههاى مختلف به صورت غيرخطى بود بايد از يك مدل تركيبى استفاده شد. به همين دليل،

\begin{tabular}{|c|c|}
\hline دقت بازشناسى (درصد) & انواع طبقه بندها \\
\hline$V \wedge$ & MLP \\
\hline VN/V & BEL \\
\hline$V \vee / 9$ & SVM \\
\hline vı & Weighted KNN \\
\hline vi & RBF \\
\hline$\Lambda \cdot$ & Mixture of NN (MoE) \\
\hline$\Lambda \cdot / v$ & MoBEL \\
\hline
\end{tabular}

استنباط مىشود كه بازشناسى هيجان "تنفر 《با دقت تقريباً • 9 درصد يعنى راحت تر از ساير هيجان ها است.

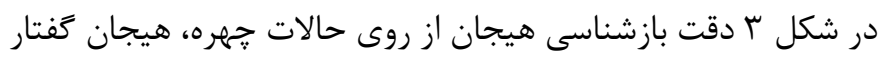
و همجوشى ويزگى ها نشان داده شده است. همان طور كه مشاهده مىشود دقت بازشناسى هيجان جندوجهى بيشتر از هر كدام از وجه ها بود. همجنين نشان داد كه مى تواند با دقت بازشناسى كم در هر يك از وجه هاى مختلف مقابله كند. به عنوان مثال در بازشناسى حالات جهره، هيجان "تعجب" داراى كمترين دقت است در حالى

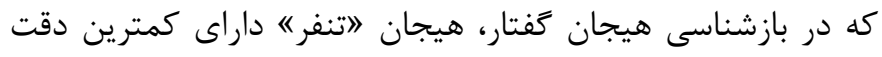

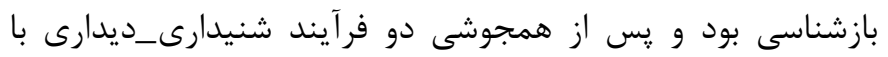

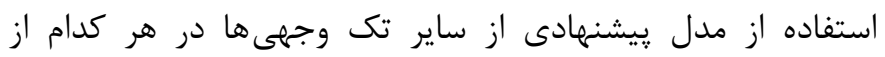

$$
\text { كلاس هاى هيجان بهتر بود. }
$$

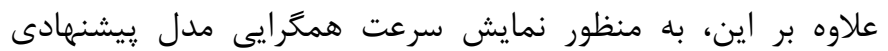

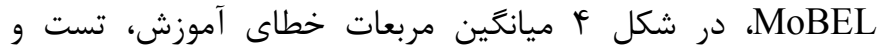
اعتبارسنجى مدل يِيشنهادى به ازاى تعداد تكرار مشخص نشان داده

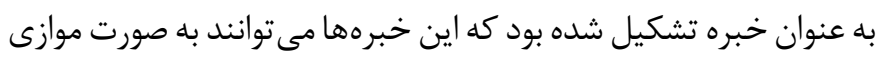

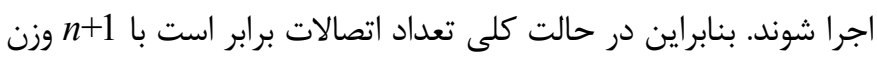

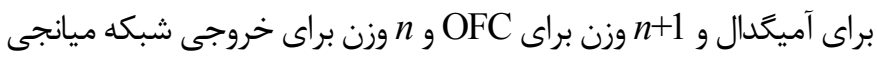

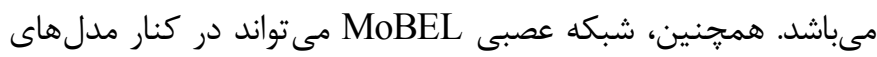
يادگيرى عميق استخراج ويزگى هاى هيجان به صورت end-to-end و بدون دخالت كاربر آموزش ببيند. ماتر يس درهمريختكى بازشناسى هيجان جندوجهى در مدل ييشنهادى همجوشى ويزگى هاى فرآيند شنيدارى_ديدارى با استفاده از مدل MoBEL در جدول Vنشان داده شده است. جالب است كه در يايگاه

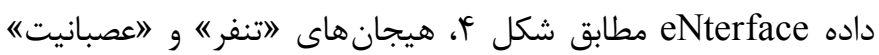

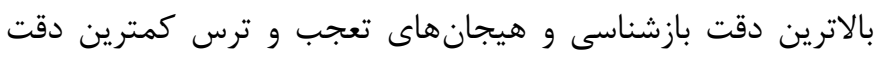

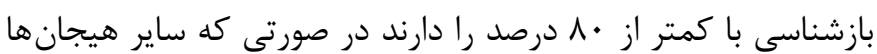
دقت بالاى •N درصد را داشتند. همجنين هيجان ترس و ناراحتى، هميوشانى بيشترى با هم دارند. به طورى كه fl| درصد از نمونه هاى هيجان ترس در ناراحتى كذاشته شده است. علاوه بر اين از اين جدول 
اعتبارسنجى مدل ييشنهادى به ازاى تعداد تكرار مشخص نشان داده شده است. مطابق شكل، مدل MOBEL بعد از r r مرحله تكرار به سرعت ياد مى گيرد و وزن هاى مدل همگرا مىشوند.
شده است. مطابق شكل، مدل MoBEL بعد از rr مرحله تكرار به سرعت ياد مى گيرد و وزن هاى مدل همخرا مىشوند. همه بهتر بود. علاوه بر اين، به منظور نمايش سرعت همخرايى مدل ييشنهادى MOBEL

جدول V. ماتريس درهم_ريختخى بازشناسى هيجان جندوجهى با استفاده از مدل MoBEL بر روى پايعاه داده eNterface'05 (درصد)

\begin{tabular}{|c|c|c|c|c|c|c|}
\hline تعجب & ناراحتى & خوشحالى & ترس & تنفر & عصبانيت & \\
\hline$r / T$ & . & T/K & r/T & $V / I$ & $\Lambda \Delta$ & عصبانيت \\
\hline . & $F / V$ & $T / \mu$ & $T / \Gamma$ & $\wedge \wedge / 1$ & $r / T$ & تنفر \\
\hline$T / r$ & if & $V / I$ & $V r / A$ & . & $T / r$ & ترس \\
\hline$F / V$ & $r / T$ & $V \wedge / 9$ & $F / V$ & $T / T$ & $V / I$ & خوشحالى \\
\hline $9 / \Delta$ & 1) & . & $9 / \Delta$ & . & $r / r$ & ناراحتى \\
\hline$v \wedge$ & $V / I$ & $V / I$ & $F / V$ & . & $r / r$ & تعجب \\
\hline
\end{tabular}

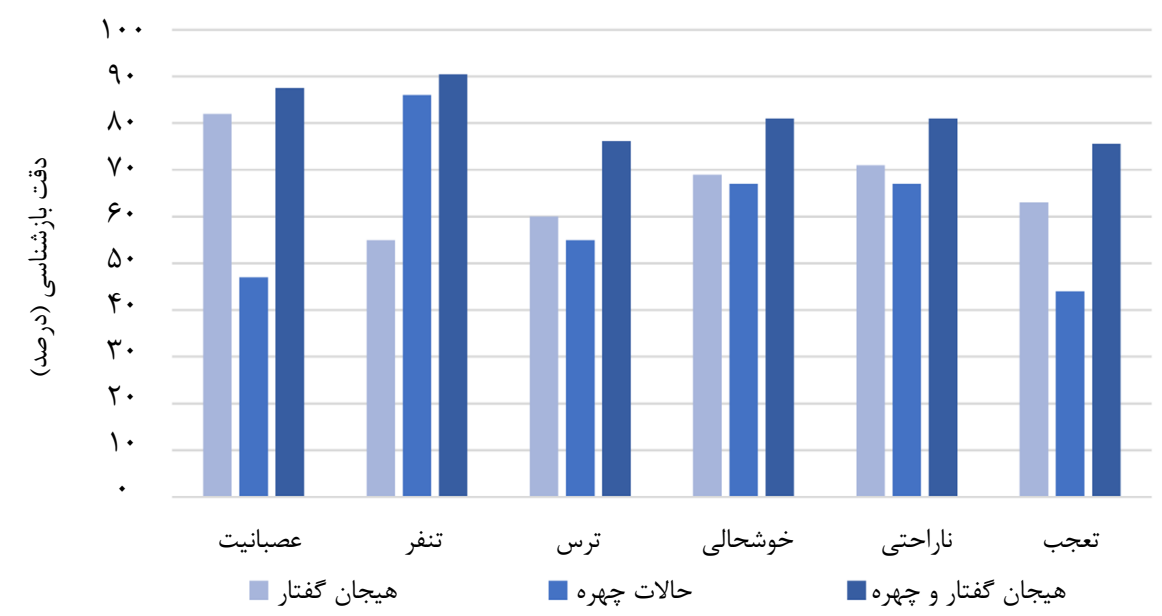

شكل r. نمودار مقايسه دقت بازشناسى هيجان از روى حالات جهره، هيجان كفتار و همجوشى فرآيند شنيدارىديدارى به ازاى هيجانهاى مختلف

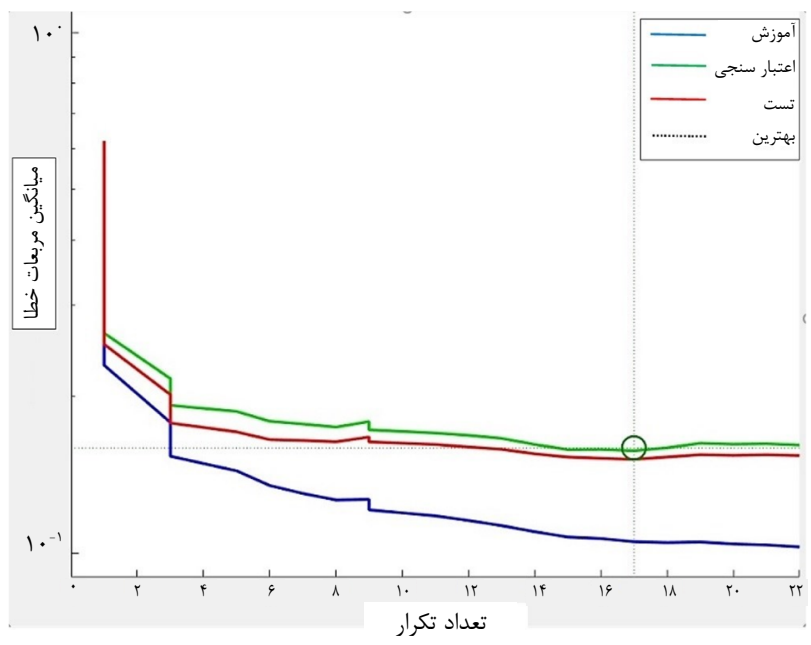

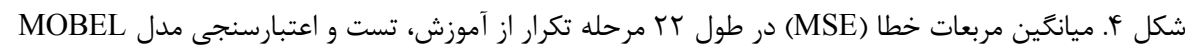


קندمداليتى، ايدهاى مختلفى در زمينههاى نظرى مى توان ارائه داد. ايده اول براى بازشناسى هيجان در ويديوهاى طولانى اين است كه

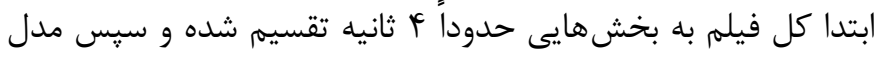
ييشنهادى در هر بخشى اعمال شود و خروجى هيجان بدست آيد. ايده

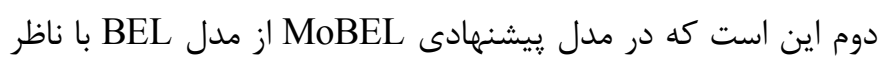

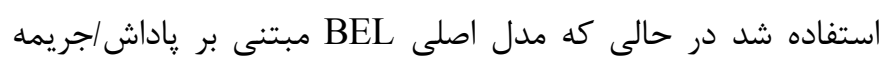

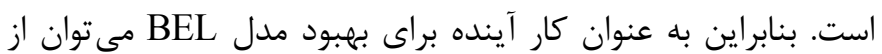
الكوريتمهاى يادكيرى عميق در سيكنال پاداش/جريمه مدل BEL استفاده كرد. همجنين با انجام يكسرى روشهاى يِيش يردازش اوليه و حذف نويز مىتوان در آينده، مدل ييشنهادى را بر روى مجموعه

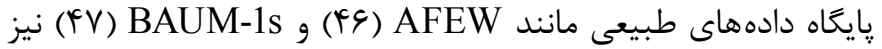

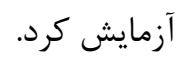

\section{نتيجه كيرى}

نوآورى اين مقاله در ارائه مدل MoBEL براى بازشناسى هيجان در ويديو بود. مدل MoBEL از خند شبكه خبره و يك شبكه ميانجى مبتنى بر مدل BEL تشكيل شده است. هدف از اين مدل، همجوشى ويزگى هاى هيجان كفتار و حالات جهره در سطوح بالاتر است به طورى كه شبكه ياد مى گيرد به كدام وجه (كَفتار يا جهره) وزن بيشترى اختصاص دهد. نتايج اين آزمايشها نشان داد كه دقت بازشناسى هيجان مدل پيشنهادى براى پايگاه داده eNterface نسبت به ساير روش هاى همجوشى بهبود يافته است.

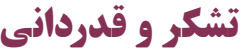

اين مقاله حاصل از باياننامه در مقطع دكترى هوش مصنوعى در دانشخاه علوم و تحقيقات آزاد اسلامى واحد تهران است.

\section{References}

1. Peter C, Beale R. The role of affect and emotion in HCI. In Peter C, Beale R, editors. Affect and emotion in HCI. Lecture notes in computer science. Vol 4868. Berlin:Springer;2008. pp. 23-34. 2. Szwoch M, Szwoch W. Emotion recognition for affect aware video games. In: Choraś R, editor. Image processing \& communications challenges. Advances in Intelligent Systems and Computing. Vol 313. New York:Springer;2015. pp. 227-236.

3. Shen L, Wang M, Shen R. Affective e-learning: Using
در اين يزوهش، ما روش جديدى براى بازشناسى هيجان جندوجهى مبتنى بر همجوشى فرآيند شنيدارى_ديدارى با استفاده از شبكه عصبى MoBEL الهام گرفته شده از سيستم ليمبيك مغز ارائه كرديم. مدل ييشنهادى ويزگى هاى ياد گرفته شده از جريانهاى بينايى و شنوايى را با استفاده از الكوريتمهاى يادگيرى عميق، به ترتيب 3D-CNN MoBEL ويزگ MoBEL همم همبستكى موجود بين ويزگى هاى شنوايى و بينايى را ياد مى گيرد و هم به عنوان يك طبقهبند، خروجى كلاس هيجان ويديو را مى دهد. اين شبكه از تركيبى از جند BEL تشكيل شده است كه الهام گرفته Associative) شده از سيستم ليمبيك مغز و نيز قشر انجمنى مغز (cortex

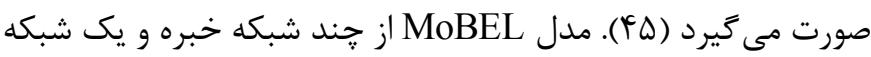
ميانجى مبتنى بر مدل BEL تشكيل شده است. همجنين يكى ديخر از جالشهاى بازشناسى هيجان در ويديو، تحليل سرى زمانى بروز هيجان در جهره و كفتار بود. به همين منظور ما از روش يادگيرى عميق 3D-CNN براى بازنمايى اطلاعات مكان_زمان هيجان جهره CNN و براى بازنمايى اطلاعات مكان_زمان هيجان كفتار استفاده كردهايم كه قدرت بالايى در تفكيك و دستهبندى كلاس هيجان نسبت به روشهاى استاتيك و دستى دارند. آزمايشات انجام شده بر روى يايگاه داده صوتى_تصويرى eNterface'05 نشان مى دهد كه مدل ييشنهادى بسيار بهتر از ساير مدلهاى قبلى كار شده در زمينه استخراج ويزگگ هاى دستى هيجان گفتار و حالات جهره و همجنين

همجوشى اطلاعات به منظور بازشناسى هيجان در ويديو مى باشد. براى ادامه خط اصلى اين :ززوهش، در زمينه بازشناسى هيجان

"emotional" data to improve learning in pervasive learning environment. Journal of Educational Technology \& Society. 2009;12(2):176-189.

4. Torous J, Friedman R, Keshavan M. Smartphone ownership and interest in mobile applications to monitor symptoms of mental health conditions. JMIR mHealth and uHealth. 2014;2(1):e2.

5. Lucey S, Ashraf AB, Cohn JF. Investigating spontaneous 
facial action recognition through AAM representations of the face. In Delac K, Grgic M, editors. Face Recognition. I-Tech Education and Publishing: Rijeka, Croatia;2007. pp. 275-286. 6. Guo G, Dyer CR. Learning from examples in the small sample case: Face expression recognition. IEEE Transactions on Systems, Man, and Cybernetics, Part B (Cybernetics). 2005;35(3):477-488.

7. Chang Y, Hu C, Feris R, Turk M. Manifold based analysis of facial expression. Image and Vision Computing. 2006;24(6):605-614.

8. Anderson K, McOwan PW. A real-time automated system for the recognition of human facial expressions. IEEE Transactions on Systems, Man, and Cybernetics, Part B (Cybernetics). 2006;36(1):96-105.

9. Pantic M, Patras I. Dynamics of facial expression: Recognition of facial actions and their temporal segments from face profile image sequences. IEEE Transactions on Systems, Man, and Cybernetics, Part B (Cybernetics). 2006;36(2):433-349.

10. Zhao G, Pietikainen M. Dynamic texture recognition using local binary patterns with an application to facial expressions. IEEE Transactions on Pattern Analysis And Machine Intelligence. 2007;29(6):915-928.

11. Dhall A, Asthana A, Goecke R, Gedeon T. Emotion recognition using PHOG and LPQ features. Face and Gesture. Santa Barbara, CA:IEEE;2011. pp. 878-883.

12. Trigeorgis G, Ringeval F, Brueckner R, Marchi E, Nicolaou MA, Schuller B, et al. Adieu features end-to-end speech emotion recognition using a deep convolutional recurrent network. 2016 IEEE International Conference on Acoustics Speech and Signal Processing (ICASSP). Shanghai;2016. pp. 5200-5204.

13. Mansoorizadeh M, Charkari NM. Multimodal information fusion application to human emotion recognition from face and speech. Multimedia Tools and Applications. 2010;49(2):277297.

14. Tran D, Bourdev L, Fergus R, Torresani L, Paluri M. Learning spatiotemporal features with $3 \mathrm{~d}$ convolutional networks. In Proceedings of the IEEE international conference on computer vision (ICCV). Santiago, Chile;2015. pp. 4489-4497.

15. Fan Y, Lu X, Li D, Liu Y. Video-based emotion recognition using CNN-RNN and C3D hybrid networks. In Proceedings of the 18th ACM International Conference on Multimodal Interaction;2016. pp. 445-450.

16. Rong J, Li G, Chen YP. Acoustic feature selection for automatic emotion recognition from speech. Information Processing \& Management. 2009;45(3):315-328.

17. Wu S, Falk TH, Chan WY. Automatic speech emotion recognition using modulation spectral features. Speech Communication. 2011;53(5):768-785.

18. Dave N. Feature extraction methods LPC, PLP and MFCC in speech recognition. International Journal for Advance Research in Engineering and Technology. 2013;1(6):1-4.

19. El Ayadi MM, Kamel MS, Karray F. Speech emotion recognition using Gaussian mixture vector autoregressive models. International Conference on Acoustics, Speech, and Signal Processing. 16-20 April 2007; Honolulu, Hawaii. Vol 4. pp. IV-957. IEEE.

20. Fersini E, Messina E, Archetti F. Emotional states in judicial courtrooms: An experimental investigation. Speech Communication. 2012;54(1):11-22.

21. Zeng Z, Tu J, Pianfetti BM, Huang TS. Audio-visual affective expression recognition through multistream fused HMM. IEEE Transactions on Multimedia. 2008;10(4):570-577.

22. Ntalampiras S, Fakotakis N. Modeling the temporal evolution of acoustic parameters for speech emotion recognition. IEEE Transactions on Affective Computing. 2011;3(1):116-125. 23. Zhang S, Zhang S, Huang T, Gao W, Tian Q. Learning affective features with a hybrid deep model for audio-visual emotion recognition. IEEE Transactions on Circuits and Systems for Video Technology. 2017;28(10):3030-3043.

24. Potamianos G, Neti C, Gravier G, Garg A, Senior AW. Recent advances in the automatic recognition of audiovisual speech. Proceedings of the IEEE. 2003;91(9):1306-1326.

25. Kahou SE, Bouthillier X, Lamblin P, Gulcehre C, Michalski V, Konda K, Jean S, et al. Emonets: Multimodal deep learning approaches for emotion recognition in video. Journal on 
Multimodal User Interfaces. 2016;10(2):99-111.

27. Lan ZZ, Bao L, Yu SI, Liu W, Hauptmann AG. Multimedia classification and event detection using double fusion. Multimedia Tools and Applications. 2014;71(1):333-347.

28. Schuller B, Müeller R, Höernler B, Höethker A, Konosu H, Rigoll G. Audiovisual recognition of spontaneous interest within conversations. In Proceedings of the 9th International Conference on Multimodal Interfaces (ICMI). Nov 12 2007; Aichi, Japan. pp. 30-37.

29. Wang Y, Guan L, Venetsanopoulos AN. Kernel cross-modal factor analysis for information fusion with application to bimodal emotion recognition. IEEE Transactions on Multimedia. 2012;14(3):597-607.

30. Gurban M, Thiran JP, Drugman T, Dutoit T. Dynamic modality weighting for multi-stream hmms inaudio-visual speech recognition. In Proceedings of the 10th international conference on Multimodal Interfaces. Oct 20; 2008. pp. 237-240.

31. Chen S, Jin Q. Multi-modal dimensional emotion recognition using recurrent neural networks. In Proceedings of the 5th International Workshop on Audio/Visual Emotion Challenge. Oct 26 2015. pp. 49-56.

32. Ngiam J, Khosla A, Kim M, Nam J, Lee H, Ng AY. Multimodal deep learning. In Proceedings of the 28th International Conference on Machine Learning. 2011 June 28-July 2; Bellevue, WA, USA;2011.

33. Balkenius C, Morén J. A computational model of emotional conditioning in the brain. In Proceedings of Workshop on Grounding Emotions in Adaptive Systems. Zurich;1998.

34. Lucas C. BELBIC and its industrial applications: towards embedded neuroemotional control codesign. In Integrated systems, design and technology 2010-2011. Berlin, Heidelberg:Springer. pp. 203-214.

35. Lotfi E, Akbarzadeh-T MR. Brain emotional learning-based pattern recognizer. Cybernetics and Systems. 2013;44(5):402-421. 36. Farhoudi Z, Setayeshi S, Rabiee A. Using learning automata in brain emotional learning for speech emotion recognition. International Journal of Speech Technology. 2017;20(3):553-562.
37. Lotfi E, Khazaei O, Khazaei F. Competitive brain emotional learning. Neural Processing Letters. 2018;47(2):745-764.

38. Fino E, Yuste R. Dense inhibitory connectivity in neocortex. Neuron. 2011;69(6):1188-1203.

39. Zhalehpour S, Onder O, Akhtar Z, Erdem CE. BAUM1: A spontaneous audio-visual face database of affective and mental states. IEEE Transactions on Affective Computing. 2016;8(3):300-313.

40. Bejani M, Gharavian D, Charkari NM. Audiovisual emotion recognition using ANOVA feature selection method and multi-classifier neural networks. Neural Computing and Applications. 2014;24(2):399-412.

41. Sahoo S, Routray A. Emotion recognition from audio-visual data using rule based decision level fusio. 2016 IEEE Students' Technology Symposium (TechSym). Kharagpur, India;2016. pp. 7-12.

42. Zhang SH, Wang XI, Zhang GA, Zhao XI. Multimodal emotion recognition integrating affective speech with facial expression. WSEAS Transactions on Signal Processing. 2014;10(2014):526-537.

43. Badshah AM, Ahmad J, Rahim N, Baik SW. Speech emotion recognition from spectrograms with deep convolutional neural network. In 2017 International Conference On Platform Technology And Service (PlatCon). Feb 13 2017;Busan. pp. 1-5. IEEE.

44. Mansoorizadeh M, Charkari NM. Speech emotion recognition: Comparison of speech segmentation approaches. In Proceedings of IKT. Mashad, Iran;2007.

45. Stein BE, Stanford TR, Rowland BA. The neural basis of multisensory integration in the midbrain: Its organization and maturation. Hearing Research. 2009;258(1-2):4-15.

46. Dhall A, Goecke R, Lucey S, Gedeon T. Collecting large, richly annotated facial-expression databases from movies. IEEE Multimedia. 2012;19(3):34-41.

47. Zhalehpour S, Onder O, Akhtar Z, Erdem CE. BAUM1: A spontaneous audio-visual face database of affective and mental states. IEEE Transactions on Affective Computing. 2016;8(3):300-313 